\title{
International collaboration between tissue banking associations
}

\author{
Ruth M. Warwick
}

Received: 22 May 2009/Accepted: 18 June 2009/Published online: 16 April 2010

(C) Springer Science+Business Media B.V. 2010

This volume of Cell and Tissue Banking is a very important Special Issue of the Journal. It clearly demonstrates the increasing international collaboration between tissue banking associations. It contains the report of the 17th International Congress of the European Association of Tissue Banks (EATB), which was held jointly with the 17th Annual Meeting of the British Association for Tissue Banking (BATB). It also included, for the very first time, a cardiovascular symposium held jointly by three tissue banking associations, EATB, BATB and the American Association of Tissue Banks (AATB). This Congress was held in November 2008 in Edinburgh, UK and received excellent evaluation from its international participants. There were 23 invited speakers who submitted elegant short papers on the subject of their talks, which are to be found in this volume, as well as the abstracts that were accepted for free papers given as either an oral presentation or poster. In addition, this volume is graced with 5 invited full papers, which were considered to be some of the best free papers that were presented at the meeting.

A report co-written with Scott Brubaker, Chief Policy Officer, AATB, John Kearney, Chair of the

R. M. Warwick ( $₫)$

National Health Service Blood and Transplant, Consultant

Specialist Tissue Services, Colindale Avenue, London

NW9 5BG, UK

e-mail: ruth.warwick@nhsbt.nhs.uk
Scientific Abstract Management Committee for the Congress, Robert Parker Chair of the Local Organising Committee, and myself as EATB President 2007-2009, describes the meeting in greater detail and is included in this Special Issue.

This volume also includes a paper from Scott Brubaker (as above), Chad J. Ronholdt, Chair, AATB Scientific and Technical Affairs Committee, 20052008 and Mark Moore, Chair-elect AATB Scientific and Technical Affairs Committee, 2009-2001. This paper describes the 32nd Annual Meeting of the AATB, which was held in Chicago, Illinois, USA and this volume also contains the abstracts from that meeting which, for the first time, were managed through an on-line submission system.

Clinical and scientific progress in tissue banking continues to be made at rapid pace. The evolving partnership between the various associations, their members and regulators and many others who contributed to the Congress have all facilitated professional dialogue, one of the many facets of cooperation that is benefiting tissue recipients and which will further develop over the years to come.

Guest Editor

CATB Special Issue EATB-BATB-AATB

President EATB 2007-2009 